\title{
Rhizobium miluonense sp. nov., a symbiotic bacterium isolated from Lespedeza root nodules
}

\author{
Correspondence \\ Wen Xin Chen \\ wenxin_chen@263.net
}

\author{
Chun Tao Gu, ${ }^{1}$ En Tao Wang, ${ }^{1,2}$ Chang Fu Tian, ${ }^{1}$ Tian Xu Han, ${ }^{1}$ \\ Wen Feng Chen, ${ }^{1}$ Xin Hua Sui ${ }^{1}$ and Wen Xin Chen ${ }^{1}$
}

\author{
${ }^{1}$ Key Laboratory of Agro-Microbial Resource and Application, Ministry of Agriculture/Department of \\ Microbiology, College of Biological Sciences, China Agricultural University, Beijing 100094, China \\ ${ }^{2}$ Departamento de Microbiología, Escuela Nacional de Ciencias Biológicas, Instituto Politécnico \\ Nacional, México DF 11340, Mexico
}

\begin{abstract}
Seventeen strains of lespedeza rhizobia, a previously defined novel group, were further characterized by comparison with phylogenetically related species using a polyphasic approach, including SDS-PAGE of whole-cell proteins, PCR-based restriction fragment length polymorphism analysis of ribosomal intergenic spacer sequences, determination of DNA G+C contents, DNA-DNA hybridization and analysis of phenotypic features. Based on data obtained in the present and previous studies, a novel species, Rhizobium miluonense sp. nov., is proposed for these strains. The type strain of $R$. miluonense is CCBAU $41251^{\top}$ (=LMG $24208^{\top}=$ HAMBI $2971^{\top}$ ). Strain CCBAU $41251^{\top}$ could form ineffective nodules on Phaseolus vulgaris in addition to its original host Lespedeza chinensis.
\end{abstract}

Rhizobia are soil bacteria that can form nodules in symbiosis with leguminous plants. Currently, about 50 rhizobial species within more than 10 genera of the alphaand betaproteobacteria have been described. Among these genera, Rhizobium was the first described species, named 100 years ago. After a series of taxonomic changes since the 1980s, the genus Rhizobium now contains about 20 species, including three recently described species: Rhizobium daejeonense (Quan et al., 2005), Rhizobium lusitanum (Valverde et al., 2006) and Rhizobium cellulosilyticum (García-Fraile et al., 2007).

In our previous study ( $\mathrm{Gu}$ et al., 2007), diverse rhizobia associated with Lespedeza spp. in temperate and subtropical regions of China were characterized and two novel Rhizobium groups (6 and 7) were identified based on $16 \mathrm{~S}$ rRNA gene sequence analysis and DNA-DNA hybridization. In the present study, the main novel group, group 7 , was further studied to clarify its taxonomic status.

Seventeen test strains in group 7 (Gu et al., 2007) and six reference strains were used in this study (Table 1). These test strains were isolated from root nodules of nine Lespedeza species grown in Hunan province, China.

Abbreviations: IGS, intergenic spacer; RFLP, restriction fragment length polymorphism.

The GenBank/EMBL/DDBJ accession number for the 16S rRNA gene sequence of Rhizobium miluonense CCBAU $41251^{\top}$ is EF061096.

Phenotypic characteristics of strains of Rhizobium miluonense sp. nov. are given in Supplementary Table S1, which is available with the online version of this paper.
Nodulation on the original host plant of each isolate has been confirmed previously (Gu et al., 2007). All strains were maintained on yeast-mannitol agar (YMA) medium at $4{ }^{\circ} \mathrm{C}$ during the study.

Previously, these 17 strains were defined as group 7 since they formed a cluster using SDS-PAGE of proteins that was distinct from reference strains and other lespedeza rhizobia at a similarity of $88 \%$. These 17 strains also clustered in PCR-based ribosomal intergenic spacer restriction fragment length polymorphism (IGS-RFLP) analysis, showing $99.5-100 \%$ similarity within the group and $70 \%$ similarity with other rhizobia ( $\mathrm{Gu}$ et al., 2007). 16S rRNA gene sequencing and phylogenetic analysis revealed that three representative strains of group 7 had identical sequences and were closely related to Rhizobium tropici type B CIAT $899^{\mathrm{T}}, R$. tropici type A LMG 9517, R. lusitanum $\mathrm{P} 1-7^{\mathrm{T}}$ and Rhizobium rhizogenes IFO $13257^{\mathrm{T}}$, with $16 \mathrm{~S}$ rRNA gene sequence similarities of $99.3,98.8,99.6$ and $99.4 \%$, respectively (Gu et al., 2007).

Since the reference strains for the Rhizobium species most related to group 7 were not included in SDS-PAGE of whole-cell proteins and IGS-RFLP analysis, these two methods were used in this study to compare the group 7 strains and the related species. For SDS-PAGE, all strains were incubated in yeast-mannitol (YM) broth at $28{ }^{\circ} \mathrm{C}$ for 2 days. The preparation of protein samples, SDS-PAGE and silver-staining of the gels were performed as described previously (Tan et al., 1997). For IGS-RFLP, the ribosomal IGS between the $16 \mathrm{~S}$ and $23 \mathrm{~S}$ rRNA genes was amplified using primers FGPS6 and 23S-38 and the 
Table 1. Bacterial strains used in this study

\begin{tabular}{|c|c|c|}
\hline Strain & Host plant & Geographical origin \\
\hline \multicolumn{3}{|l|}{ Cluster 7 ( $R$. miluonense): } \\
\hline CCBAU 41005, CCBAU 41018, CCBAU 41141 & Lespedeza davidii & Hunan \\
\hline CCBAU 41031, CCBAU 41126 & Lespedeza cuneata & Hunan \\
\hline CCBAU 41041, CCBAU 41114, CCBAU 41132 & Lespedeza pilosa & Hunan \\
\hline CCBAU 41068 & Lespedeza virgata & Hunan \\
\hline CCBAU 41164 & Lespedeza cyrtobotrya & Hunan \\
\hline CCBAU 41200 & Lespedeza bicolor & Hunan \\
\hline CCBAU 41216 & Lespedeza tomentosa & Hunan \\
\hline R. tropici type A CFN 299 (=LMG 9517) & Phaseolus vulgaris & Brazil \\
\hline R. tropici type B LMG $9503^{\mathrm{T}}\left(=\mathrm{CIAT} 899^{\mathrm{T}}\right)$ & Leucaena leucocephala & Colombia \\
\hline R. lusitanum $\mathrm{LMG} 22705^{\mathrm{T}}\left(=\mathrm{P} 1-7^{\mathrm{T}}\right)$ & Phaseolus vulgaris & Portugal \\
\hline
\end{tabular}

protocol of Rasolomampianina et al. (2005). The PCR products were digested separately with $M s p \mathrm{I}, C f o \mathrm{I}$ and HaeIII as described by Rasolomampianina et al. (2005). Restriction fragments were separated by electrophoresis in $3 \%$ agarose gels and photographed under UV light after ethidium bromide staining. Cluster analyses of the protein and RFLP patterns were performed as described previously (Gu et al., 2007).

In both SDS-PAGE of proteins and ribosomal IGS-RFLP analysis, the 17 strains of group 7 showed almost identical patterns (99-100\% similarity). Similarities between the group 7 strains and R. tropici type B LMG $9503^{\mathrm{T}}, R$. tropici type A CFN 299, $R$. lusitanum LMG $22705^{\mathrm{T}}$ and $R$. rhizogenes LMG $150^{\mathrm{T}}$ were $\leqslant 64.5 \%$ in SDS-PAGE of whole-cell proteins (Fig. 1) and $\leqslant 81 \%$ in ribosomal IGSRFLP analysis (Fig. 2). These data demonstrated that members of group 7 differed from phylogenetically related Rhizobium species.
Previously, DNA-DNA hybridization has been performed between group 7 strain CCBAU $41251^{\mathrm{T}}$ and the reference strains of several defined species. To determine the relationships between group 7 strains and all the most related species, DNA G + C contents were determined and further DNADNA hybridizations were performed. The DNA was prepared according to the method of Marmur (1961). DNA $G+C$ contents were measured using the thermal melting protocol of De Ley (1970) with Escherichia coli K-12 as the standard. DNA relatedness was determined by the initial renaturation rate method (De Ley et al., 1970). The DNA G $+\mathrm{C}$ contents of the three group 7 strains CCBAU $41251^{\mathrm{T}}$, CCBAU 41029 and CCBAU 41128 were 58.4, 58.8 and $58.2 \mathrm{~mol} \%$, respectively. The DNA-DNA relatedness data are presented in Table 2. Low to medium DNA-DNA relatedness (15-45\%) was obtained between strain CCBAU $41251^{\mathrm{T}}$ and six reference strains of $R$. tropici type B, R. tropici type A, R. lusitanum and $R$. rhizogenes (Table 2). DNA-DNA

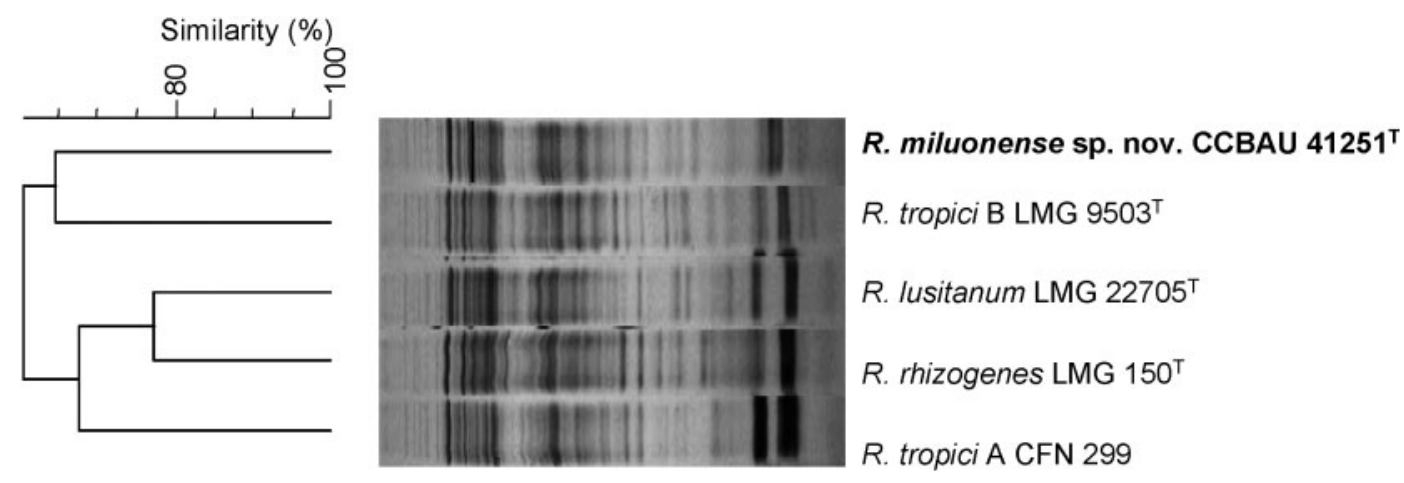

Fig. 1. Electrophoretic protein patterns showing the relationships between strain CCBAU $41251^{\top}$ and reference strains of phylogenetically related species. Patterns for the other 16 strains in group 7 (Table 1) were almost identical to that of strain CCBAU $41251^{\top}$. 


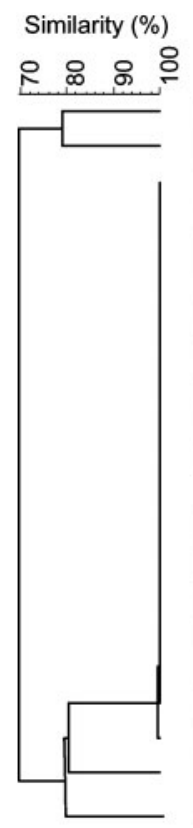

Cfol

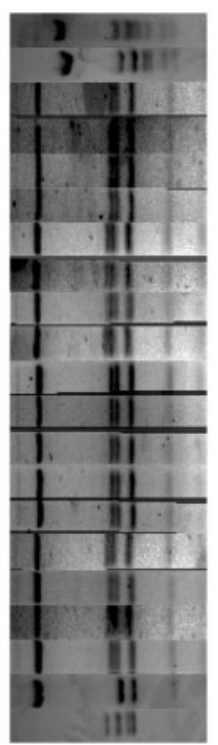

Mspl

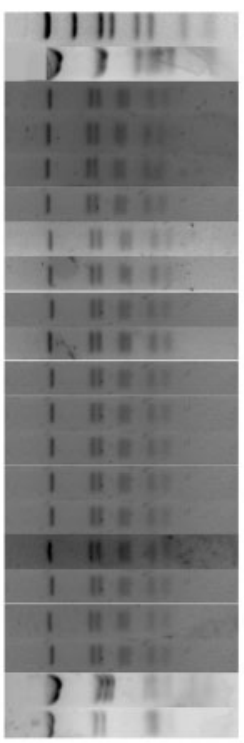

HaellI

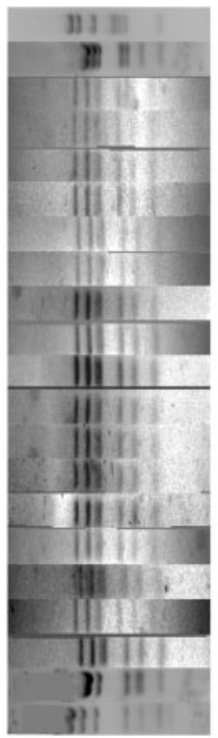

R. tropici A CFN 299

$R$. rhizogenes LMG $150^{\top}$

CCBAU 41029

CCBAU 41108

CCBAU 41114

CCBAU 41128

CCBAU 41068

CCBAU 41018

CCBAU 41005

CCBAU 41132

CCBAU 41200

CCBAU 41031

CCBAU 41126

CCBAU 41164

CCBAU $41251^{\top}$

CCBAU 41041

CCBAU 41231

CCBAU 41216

CCBAU 41141

R. tropici B LMG $9503^{\top}$

R. Iusitanum LMG $22705^{\top}$

Fig. 2. Ribosomal IGS-RFLP patterns showing the genomic relationships between strains of $R$. miluonense sp. nov. and phylogenetically related reference strains.

relatedness of $96-100 \%$ was obtained between strain CCBAU $41251^{\mathrm{T}}$ and two other strains that were randomly selected as representatives of group 7 (Table 2). The large gap between the DNA-DNA relatedness values within the group and with the reference strains obviously indicated that the group 7 strains formed a genomic species that differed from related Rhizobium species.

To clarify whether the group 7 strains could be defined as a species, phenotypic features that differentiated group 7 from related species were analysed according to the current criterion of bacterial species definition (Stackebrandt et al., 2002). In the present study, phenotypic features, including the utilization of sole carbon and nitrogen sources, resistance to antibiotics, tolerance to $\mathrm{NaCl}$ and $\mathrm{pH}$ and temperature ranges for growth (see Supplementary Table S1, available in IJSEM Online) were analysed as described previously (Gao et al., 1994). Among the 96 tested features, 68 were the same (positive or negative) for all the strains. In the cluster analysis (Fig. 3) using the $S_{\mathrm{SM}}$ coefficient $\left(S_{\mathrm{SM}}=\Sigma \mathrm{I} / 96\right.$, where $\Sigma \mathrm{I}$ is the number of features identical for the compared strain pair; 96 is the total number of tested features) and unweighted pair-group method with arithmetic averages (UPGMA) (Sneath \& Sokal, 1973), the 17 strains in group 7 showed $98.5 \%$ or greater similarity and clearly differed from the reference strains of recognized

Table 2. DNA-DNA relatedness between strain CCBAU $41251^{\top}$ and phylogenetically related reference strains

Data are mean values of at least three repetitions.

\begin{tabular}{|c|c|}
\hline Strain & DNA relatedness (\%) with CCBAU $41251^{\mathrm{T}}$ \\
\hline \multicolumn{2}{|l|}{ R. miluonense sp. nov. } \\
\hline CCBAU $41251^{\mathrm{T}}$ & 100 \\
\hline CCBAU 41029 & 100 \\
\hline CCBAU 41128 & 96 \\
\hline R. tropici A CFN 299 & 29 \\
\hline R. tropici B LMG $9503^{\mathrm{T}}$ & 34 \\
\hline R. rhizogenes LMG $150^{\mathrm{T}}$ & 24 \\
\hline R. rhizogenes LMG 152 & 20 \\
\hline R. lusitanum $\mathrm{LMG} 22705^{\mathrm{T}}$ & 45 \\
\hline R. lusitanum P3-13 & 15 \\
\hline
\end{tabular}




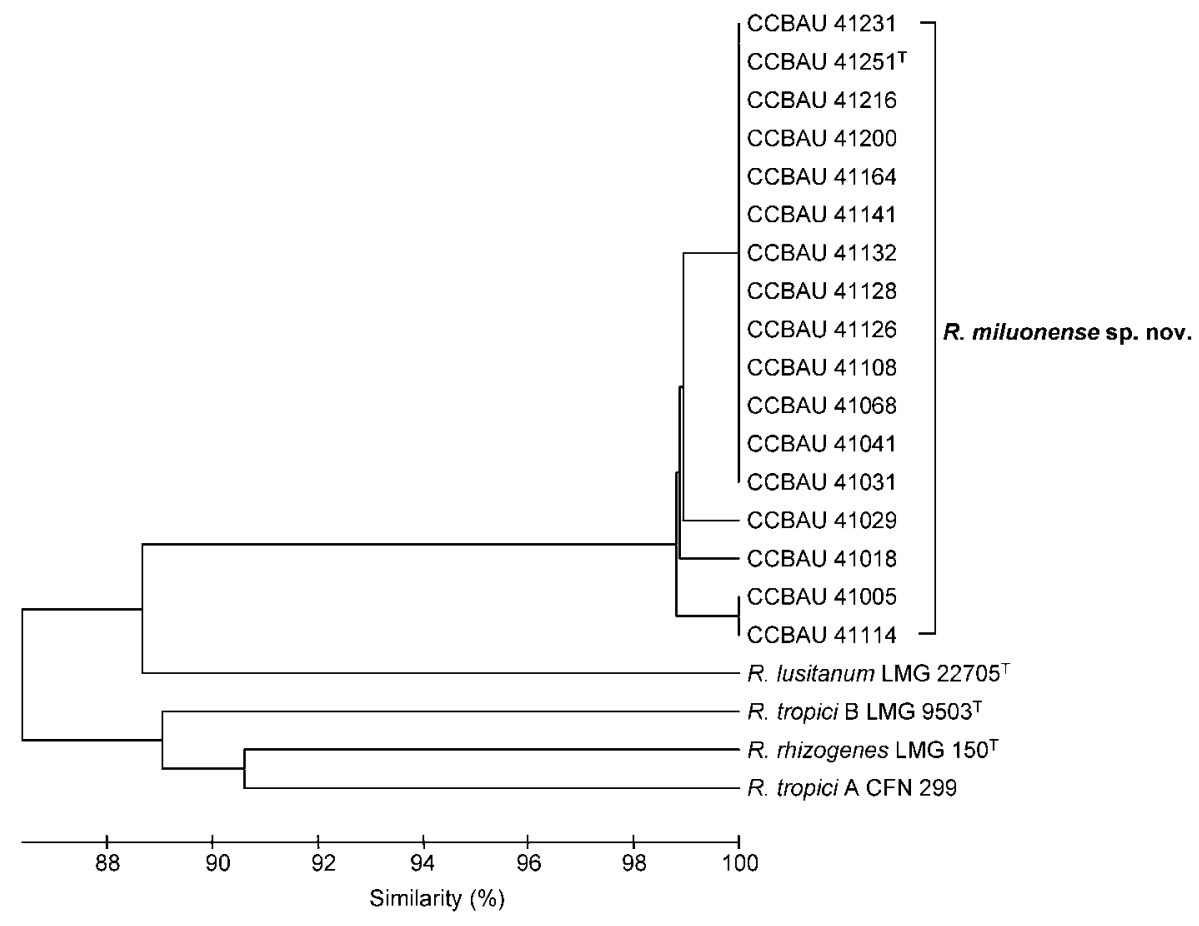

Fig. 3. Dendrogram showing the phylogenetic relationships among strains of $R$. miluonense sp. nov. and phylogenetically related reference strains. The dendrogram was constructed based upon 96 phenotypic features using $S_{\mathrm{SM}}$ coefficients and the UPGMA method (Sneath \& Sokal, 1973).

species (Fig. 3). Distinctive features of group 7 are shown in Table 3 and more features are presented in the species description. In this analysis, colony morphology (i.e. wet and translucent) could distinguish group 7 strains from $R$. tropici type $\mathrm{A}$ and $R$. rhizogenes, whereas no growth in Luria-Bertani (LB) medium and sensitivity to $1 \% \mathrm{NaCl}$ could differentiate group 7 strains from $R$. tropici type B and R. lusitanum.

To check the host range, seeds of Phaseolus vulgaris, Medicago sativa, Pisum sativum and Leucaena leucocephala were surface-sterilized, germinated and inoculated with the representative strain CCBAU $41251^{\mathrm{T}}$ according to standard protocols (Vincent, 1970). The growth conditions of the plants were as described previously (Yao et al., 2002). After 7 weeks of growth, inefficient (white) nodules were observed on Phaseolus vulgaris inoculated with strain CCBAU $41251^{\mathrm{T}}$, but no nodules were found on Medicago sativa, Pisum sativum or Leucaena leucocephala. This failure to nodulate $P$. vulgaris effectively might be an additional phenotypic feature to enable the differentiation of group 7 members from related species since $R$. tropici, $R$. rhizogenes

Table 3. Distinctive features of $R$. miluonense sp. nov. and phylogenetically related species

Strains: 1, R. miluonense CCBAU $41251^{\mathrm{T}}$ sp. nov.; 2, R. tropici A CFN 299; 3, R. tropici B LMG $9503^{\mathrm{T}}$; 4, R. lusitanum LMG $22705^{\mathrm{T}}$; 5, R. rhizogenes LMG $150^{\mathrm{T}}$. -, No growth; +, growth; \pm , light growth.

\begin{tabular}{|c|c|c|c|c|c|}
\hline Characteristic & 1 & 2 & 3 & 4 & 5 \\
\hline \multicolumn{6}{|l|}{ Resistance to $\left(\mu \mathrm{g} \mathrm{ml}^{-1}\right)$ : } \\
\hline Ampicillin (300) & - & - & + & - & - \\
\hline Chloramphenicol (50) & - & - & + & \pm & - \\
\hline Kanamycin sulfate (5) & - & - & - & + & + \\
\hline Streptomycin sulfate (50) & - & - & + & - & - \\
\hline Growth on LB & - & - & + & \pm & - \\
\hline Tolerance to $1 \% \mathrm{NaCl}(\mathrm{w} / \mathrm{v})$ & - & - & + & \pm & - \\
\hline Colony morphology on YMA & $\begin{array}{c}\text { Wet, trans- } \\
\text { lucent }\end{array}$ & Opaque & $\begin{array}{c}\text { Wet, trans- } \\
\text { lucent }\end{array}$ & $\begin{array}{c}\text { Wet, trans- } \\
\text { lucent }\end{array}$ & Opaque \\
\hline
\end{tabular}


and $R$. lusitanum strains could form effective root nodules with this plant (Valverde et al., 2006).

In conclusion, the 17 strains in group 7 were very similar in all the genomic and phenotypic analyses. They were identified as members of the genus Rhizobium and were related to $R$. tropici, $R$. rhizogenes and $R$. lusitanum by $16 \mathrm{~S}$ rRNA gene sequencing (Gu et al., 2007), but formed a group that differed from the recognized species of the genus Rhizobium in SDS-PAGE of proteins (Fig. 1), ribosomal IGS-RFLP (Fig. 2), DNA-DNA hybridization (Table 2) and numerical taxonomy (Fig. 3). Taking the recently reported Rhizobium species as references (García-Fraile et al., 2007; Quan et al., 2005; Valverde et al., 2006), the strains in group 7 could be defined as a novel species of the genus Rhizobium based on the results presented in this study and in our previous work ( $\mathrm{Gu}$ et al., 2007); the name proposed for this species is Rhizobium miluonense sp. nov.

\section{Description of Rhizobium miluonense sp. nov.}

Rhizobium miluonense (mi.lu.o.nen'se. N.L. fem. adj. miluonense pertaining to the Miluo River, a famous river located in Hunan Province, where the bacterium was isolated).

Aerobic, Gram-negative, non-spore-forming rods, 0.6$0.8 \times 1.8-3.2 \mu \mathrm{m}$. Colonies on YMA are circular, convex, translucent and usually $2-3 \mathrm{~mm}$ in diameter after 3 days incubation at $28{ }^{\circ} \mathrm{C}$. Amygdalin, D-arabinose, calcium gluconate, calcium malonate, meso-erythritol, D-fructose, Dgalactose, D-glucose, inositol, lactose, sodium DL-malate, maltose, D-mannose, turanose, raffinose, L-rhamnose, salicin, sodium citrate, sodium D-gluconate, sodium succinate, sorbose, sucrose, trehalose, D-xylose, L-arginine, L-proline and L-aspartic acid are used as sole carbon sources for growth, but adipic acid, dextrin, inulin, melezitose, sodium acetate, sodium formate, sodium hippurate, soluble starch, syringic acid, potassium sodium tartrate, vanillic acid, glycine, Lthreonine and L-methionine are not utilized. DL- $\alpha-$ Aminopropionic acid, L-arginine, L-aspartic acid, L-cystine, D-glutamic acid, L-glutamic acid, hypoxanthine, L-isoleucine, L-lysine, L-phenylalanine, L-valine, glycine, L-threonine and Lhydroxyproline are used as sole nitrogen sources for growth, but D-threonine is not utilized. Resistant to $100 \mu \mathrm{g}$ ampicillin $\mathrm{ml}^{-1}$ and $5 \mu \mathrm{g} \mathrm{ml}^{-1}$ each of chloramphenicol, neomycin sulfate and streptomycin sulfate. Sensitive to $300 \mu \mathrm{g}$ ampicillin $\mathrm{ml}^{-1}, 5 \mu \mathrm{g} \mathrm{ml}^{-1}$ each of gentamicin sulfate, erythromycin and kanamycin sulfate, and $50 \mu \mathrm{g} \mathrm{ml}^{-1}$ each of chloramphenicol, neomycin sulfate and streptomycin sulfate. Optimum growth temperature is $25-30{ }^{\circ} \mathrm{C}$; can grow at $37^{\circ} \mathrm{C}$, but not $4{ }^{\circ} \mathrm{C}$. Optimum $\mathrm{pH}$ is $6-8$. Sensitive to $1 \%(\mathrm{w} / \mathrm{v})$ $\mathrm{NaCl}$ in YMA. Does not grow in Luria-Bertani medium.

The type strain is CCBAU $41251^{\mathrm{T}}$ (=LMG $24208^{\mathrm{T}}$ $=$ HAMBI $2971^{\mathrm{T}}$ ), isolated from root nodules of Lespedeza species grown in Hunan province, China. The DNA $\mathrm{G}+\mathrm{C}$ content of strain CCBAU $41251^{\mathrm{T}}$ is $58.4 \mathrm{~mol} \%$.

\section{Acknowledgements}

This work was supported by the foundation of the National Basic Research Program of China (2006CB100206) and the foundation of the National Program for Basic $S$ \& $T$ Platform Construction (2005DKA21201-10) and the National Natural Science Foundation of China (30400001 and 30670001). We thank Professor Encarna Velázquez for kindly supplying us with $R$. lusitanum P3-13. E. T.W. was supported financially by projects of SIP 20060213 and SIP20070538 authorized by IPN, Mexico.

\section{References}

De Ley, J. (1970). Reexamination of the association between melting point, buoyant density, and chemical base composition of deoxyribonucleic acid. J Bacteriol 101, 738-754.

De Ley, J., Cattoir, H. \& Reynaerts, A. (1970). The quantitative measurement of DNA hybridization from renaturation rates. Eur $J$ Biochem 12, 133-142.

Gao, J. L., Sun, J. G., Li, Y., Wang, E. T. \& Chen, W. X. (1994). Numerical taxonomy and DNA relatedness of tropical rhizobia isolated from Hainan Province, China. Int J Syst Bacteriol 44, 151-158.

Garcia-Fraile, P., Rivas, R., Willems, A., Peix, A., Martens, M., Martínez-Molina, E., Mateos, P. F. \& Velázquez, E. (2007). Rhizobium cellulosilyticum sp. nov., isolated from sawdust of Populus alba. Int J Syst Evol Microbiol 57, 844-848.

Gu, C. T., Wang, E. T., Sui, X. H., Chen, W. F. \& Chen, W. X. (2007). Diversity and geographical distribution of rhizobia associated with Lespedeza spp. in temperate and subtropical regions of China. Arch Microbiol 188, 355-365.

Marmur, J. (1961). A procedure for the isolation of deoxyribonucleic acid from microorganisms. J Mol Biol 3, 208-218.

Quan, Z.-X., Bae, H.-S., Baek, J.-H., Chen, W.-F., Im, W.-T. \& Lee, S.- T. (2005). Rhizobium daejeonense sp. nov. isolated from a cyanide treatment bioreactor. Int J Syst Evol Microbiol 55, 2543-2549.

Rasolomampianina, R., Bailly, X., Fetiarison, R., Rabevohitra, R., Béna, G., Ramaroson, L., Raherimandimby, M., Moulin, L., De Lajudie, P. \& other authors (2005). Nitrogen-fixing nodules from rose wood legume trees (Dalbergia spp.) endemic to Madagascar host seven different genera belonging to $\alpha$ - and $\beta$-Proteobacteria. Mol Ecol 14, 4135-4146.

Sneath, P. H. A. \& Sokal, R. R. (1973). Numerical Taxonomy. The Principles and Practice of Numerical Classification. San Francisco: W. H. Freeman.

Stackebrandt, E., Frederiksen, W., Garrity, G. M., Grimont, P. A. D., Kämpfer, P., Maiden, M. C. J., Nesme, X., Rosselló-Mora, R., Swings, J. \& other authors (2002). Report of the ad hoc committee for the reevaluation of the species definition in bacteriology. Int J Syst Evol Microbiol 52, 1043-1047.

Tan, Z. Y., Xu, X. D., Wang, E. T., Gao, J. L., Martínez-Romero, E. \& Chen, W. X. (1997). Phylogenetic and genetic relationships of Mesorhizobium tianshanense and related rhizobia. Int J Syst Bacteriol 47, 874-879.

Valverde, A., Igual, J. M., Peix, A., Cervantes, E. \& Velázquez, E. (2006). Rhizobium lusitanum sp. nov., a bacterium that nodulates Phaseolus vulgaris. Int J Syst Evol Microbiol 56, 2631-2637.

Vincent, J. M. (1970). A Manual for the Practical Study of the RootNodule Bacteria. Oxford: Blackwell Scientific.

Yao, Z. Y., Kan, F. L., Wang, E. T., Wei, G. H. \& Chen, W. X. (2002). Characterization of rhizobia that nodulate legume species of the genus Lespedeza and description of Bradyrhizobium yuanmingense sp. nov. Int J Syst Evol Microbiol 52, 2219-2230. 